http://dx.doi.org/10.12775/szhf.2016.011

ADAM GRZEGORZYCA

Uniwersytet Opolski, Opole, Polska

ADAM_LOGOS@INTERIA.PL

\title{
Jan Szkot Eriugena w kontekście narodowościowym, historycznym i filozoficznym
}

Dziesiątego czerwca 2009 roku Benedykt XVI podczas audiencji generalnej zaproponował zgromadzonym wspomnienie filozofa, którego poglądy zostały potępione przez dwa synody i dwóch papieży. Minęły 1154 lata od pierwszego potępienia do chwili, gdy papież wypowiedział znamienne słowa: „Dzisiaj pragnę mówić o Janie Szkocie Eriugenie, wybitnym myślicielu chrześcijańskiego Zachodu, o którego pochodzeniu wiemy niewiele" ${ }^{\text {. Filozofia }}$ Eriugeny bywała ujmowana jako panteistyczna wizja rzeczywistości sprzeczna z chrześcijaństwem lub patrystyka; jako chrześcijański neoplatonizm lub scholastyka. Warto więc, zdaniem autora, podjąć próbę ukazania Jana Szkota w trzech kontekstach - narodowościowym, historycznym i filozoficznym, zarysowując jednocześnie bogactwo myśli, które oddziaływało przez wieki oraz problemy, na które papież zwraca uwagę stwierdzeniem: „Prawdę mówiąc, dzieło teologiczne Jana Szkota nie cieszyło się wielkim powodzeniem. Jego dzieła popadły w zapomnienie nie tylko ze względu na koniec ery karolińskiej; cień na jego postać rzuciła również cenzura ze strony władzy kościelnej. Jan Szkot jest w rzeczywistości przedstawicielem radykalnego platonizmu,

${ }^{1}$ Benedykt XVI, Jan Szkot Eriugena, Audiencja Generalna 10 czerwca 2009 roku, „L'Osservatore Romano" 9/2009. 
który niekiedy wydaje się bliski wizji panteistycznej, choć jego subiektywne intencje były zawsze ortodoksyjne"2.

\section{Kontekst narodowościowy}

Określenie filozofa Eriugeną rozpowszechniło się poprzez wydanie jego pism przez Thomasa Gale’a w 1681 roku$^{3}$. Gale uważał, że filozof był Anglikiem i przygotowując oksfordzkie wydanie jego pism, w przedmowie używa wobec Jana Szkota określenia Eriugena nawiązując do nazwy angielskiego miasta Eriuven, którego właścicielem był książę Herford ${ }^{4}$. Gale rozpowszechnił określenie Eriugena, jednak jego skojarzenie z angielskim miasteczkiem i pominięcie lub nieznajomość faktu, że Jan Szkot w innym kontekście sam siebie nazwał Eriugena, doprowadziły go do błędnego wniosku, że filozof był Anglikiem. Irlandczyków i Szkotów określano często jako Iroszkotów. W stosunku do Anglików nie używano tej nazwy. Iroszkoci w czasach zaniku starożytnych wartości w Europie kontynentalnej zachowali i pielęgnowali w celtyckiej Irlandii antyczne dziedzictwo. Jerzy Strzelczyk podaje, iż dwie fale migracji Iroszkotów do Europy kontynentalnej miały szczególne znaczenie dla duchowego i intelektualnego rozwoju średniowiecznej Europy. Pierwsza fala pogłębiła i umocniła życie religijne w państwie Franków, a druga przyczyniła się do rozwoju intelektualnego w okresie renesansu karolińskiego ${ }^{5}$. Jan Szkot urodził się prawdopodobnie w Irlandii i obecnie powszechnie uważany jest za Irlandczyka. E. Gilson jednoznacznie określa pochodzenie i narodowość Eriugeny, pisząc „.... Corpus areopagitacium, z entuzjazmem powitany przez Irlandczyka Szkota Eriugenę"6. O irlandzkim pochodzeniu świadczy również przydomek Szkot, ponieważ Irlandię w czasach Eriugeny nazywano Szkocją. Samo określenie Eriugena oznacza przybywającego z Hiberni lub z Eriu, a Hibernia i Eriu, to w czasach Eriugeny, Irlandia. Sam Jan Szkot, na początku swego tłumaczenia dzieł Pseudo-Dionizego, nazywa

2 Tamże.

${ }^{3}$ Zob. Eriugena, Komentarz do Ewangelii Jana z Homilia do Prologu Ewangelii Jana, Wstęp, przełożyła A. Kijewska, Kęty 2000, s. 3.

${ }^{4}$ Zob. Eriugena, Periphyseon, Księga I, przełożyła, wstępem i komentarzami opatrzyła Agnieszka Kijewska, Kęty 2009, s. 18.

${ }^{5}$ Zob. J. Strzelczyk, Iroszkoci w kulturze średniowiecznej Europy, Warszawa 1987, s. 247.

${ }^{6}$ E. Gilson, Historia filozofii chrześcijańskiej w wiekach średnich, przeł. S. Zalewski, Warszawa 1987, s. 104. 
siebie Eriugena, czyli w nawiązaniu do języka greckiego, nazywa siebie tym, który pochodzi z Irlandii.

\section{Kontekst europejskiej historii powszechnej}

Od czasów renesansu powszechne dzieje świata dzieli się na trzy podstawowe okresy: starożytność, średniowiecze i nowożytność. Humaniści odrodzenia zaakceptowali taki podział, którego autorem był Christoph Keller (Cellarius), profesor Uniwersytetu w Halle ${ }^{7}$ Termin średniowiecze od 1688 roku funkcjonuje w większości języków świata i nie został do chwili obecnej obalony ${ }^{8}$. Opublikowany przez Kellera podręcznik historii powszechnej wyznacza początek średniowiecza na 306 rok (objęcie tronu przez Konstantyna Wielkiego). Datowanie początku i końca tej epoki jest obiektem sporów toczących się również współcześnie. Zdania historyków są podzielone, ponieważ procesy konstytutywne dla końca starożytności i początku średniowiecza miały różne konteksty i nie przebiegały szybko. W historii chrześcijaństwa średniowiecze rozpoczyna się od objęcia tronu przez Konstantyna Wielkiego. W historii Zachodniego Cesarstwa średniowiecze rozpoczyna się cesarską koronacją Karola Wielkiego w 800 roku. Najczęściej periodyzacja dziejów opiera się na wydarzeniach politycznych, a początek średniowiecza datuje się na rok 378 (zwycięstwo Wizygotów nad Rzymianami), 395 (śmierć Teodozjusza Wielkiego), 476 (obalenie cesarza Romulusa Augustulusa). Historycy proponują również datowanie związane z okresami przejściowymi, tzn. kryzysem Rzymu w III wieku, wędrówką ludów w V i VI wieku, najazdem Longobardów, rozprzestrzenianiem się islamu w VI i VII wieku oraz najazdem Arabów w VIII wieku. „W historii duchowej więcej waży rok 529, gdy zaszły dwa wydarzenia o znaczeniu symbolicznym: cesarz Justynian zamyka istniejącą prawie 1000 lat w Atenach Akademię Platońską, a Benedykt z Nursji tworzy swój zakon na Monte Cassino" ". Trwające według niektórych periodyzacji ponad 1000 lat średniowiecze dzieli się na kolejne okresy, a historycy nie są jednomyślni w tej sprawie i różnie datują te podziały. Aż sześć wieków, według niektórych historyków, powinno wyłączyć się z epoki średniowiecza, uznając je za epokę odrębną, aktualnie bez nazwy. Okres ten to wieki od

\footnotetext{
7 Zob. W. Seńko, Jak rozumieć filozofię średniowieczna, Kęty 2001, s. 5.

${ }^{8}$ Zob. T. Manteuffel, Historia Powszechna, Średniowiecze, Warszawa 1996, s. 6.

${ }_{9}^{9}$ R. Heinzmann, Filozofia średniowieczna, przeł. P. Domański, Kęty 1999, s. 5.
} 
III do VIII ${ }^{10} \mathrm{i}$ odpowiada on wczesnemu średniowieczu oraz bywa kojarzony z całkowitym upadkiem kultury. Często uważa się, że symboliczną datą, bez związków politycznych, która wyznacza koniec wczesnego średniowiecza jest rok 1000. Jan Szkot Eriugena żył najprawdopodobniej w latach $810-877^{11}$, co sprawia, że w kontekście powszechnych dziejów Europy datowanych na podstawie wszystkich wykazanych powyżej kryteriów, według obowiązującej obecnie periodyzacji, przynależy do średniowiecza, a dokładniej do wczesnego średniowiecza. Okres ten bywa nazywany wiekami ciemnymi ze względu na proces postępującej degradacji antycznej kultury przyspieszany najazdami i wielką wędrówką ludów. Pod naporem barbarzyńców w 476 roku upadło Cesarstwo Zachodniorzymskie, a plemiona zaczęły podbijać się nawzajem. Frankowie pod przywództwem Chlodwiga w 486 roku pokonali ostatniego namiestnika rzymskiego w Galii. W 497 roku Chlodwig przyjął katolicki chrzest. Trzysta lat później państwo Franków stanowiło już silny organizm polityczny. W 800 roku, po koronacji Karola Wielkiego na cesarza rzymskiego, przekształciło się w Imperium Karolińskie, by następnie, już po śmierci Karola, zmienić nazwę na Cesarstwo Rzymskie. Antyczne dziedzictwo w tych niespokojnych czasach zachowało się w Irlandii, w Bizancjum oraz w podbitej przez Arabów Hiszpanii, a zwiastuny kulturalnego odrodzenia to zapoczątkowany przez Karola Wielkiego renesans karoliński oraz okres panowania Alfreda Wielkiego w Anglii. Określenie renesans karoliński budzi wiele kontrowersji, choć istotny rozkwit edukacji, kultury i nauki, zapoczątkowany przez Karola i kontynuowany przez Karolingów ${ }^{12}$, jest potwierdzonym faktem historycznym.

Carolus invictus wybija się ponad innych władców obu frankijskich dynastii nie z powodu prowadzenia wojen, lecz dzięki szerokiemu spektrum jego wewnętrznej inicjatywy politycznej oraz płynącego z jego osobistej potrzeby podwyższania ogólnego kulturalnego i oświatowego poziomu, który w chwili obejmowania przez niego władzy był bardzo niski. Tę działalność Karola wielkiego nazwano 'renesansem karolińskim. Takie określenie zaproponował w 1839 roku francuski historyk literatury Jean-Jacques Ampěre i ono się przyjęło ${ }^{13}$.

\footnotetext{
${ }^{10}$ Zob. R. Michałowski, Historia powszechna. Średniowiecze, Warszawa 2009, s. 12.

${ }^{11}$ Zob. W. Stróżewski, Ontologia, Kraków 2004, s. 237.

${ }^{12}$ Zob. Eriugena, Periphyseon, Ksiega I, dz. cyt., s. 5.

${ }^{13}$ G. Faber, Merowingowie i Karolingowie, przeł. Z. Jaworski, Warszawa 1994, s. 174.
} 
Renesans charakteryzował się królewskim patronatem nad zachodzącymi przemianami. Karol nakazał utworzenie przy każdej diecezji szkół z podstawą programową obejmującą naukę czytania, pisania, znajomości kalendarza i gramatyki oraz rozważania Psalmów. Napominał biskupstwa i klasztory, by dla zrozumienia chrześcijańskiego nauczania troszczyły się nie tylko o życie religijne, lecz także o rozwój edukacji wśród duchowieństwa i świeckich. Uważał, że edukacja powinna opierać się na biegłości w sztukach wyzwolonych i znajomości Pisma Świętego. W realizację projektu zaangażował ówczesnych uczonych: Piotra z Pizy, Pawła Diakona i Alkuina z Yorku, który odegrał najistotniejszą rolę w przygotowaniu i przeprowadzeniu reform. Program Alkiuna zakładał, że człowiek naturalnie pragnie wiedzy, a zdobywanie jej ściśle wiąże się z procesem wznoszenia się od tego, co niższe ku temu, co wyższe, czyli od sztuk wyzwolonych do rozważania Pisma Świętego, które „(...) stało w centrum karolińskiej uczoności (...)”14. „Lekturę Pisma Świętego ułatwiała i uzupełniała lektura pism Ojców Kościoła. Jeśli jedną z podstawowych cech renesansu stanowi idea powrotu do starożytności, to niewątpliwie wybijającym się rysem renesansu karolińskiego była idea powrotu do starożytności chrześcijańskiej”"15. Renesans nawiązywał do kultury greckiej pogańskiej i chrześcijańskiej, a na dworze panowała moda na wszystko, co greckie. Bardzo istotnym etapem w recepcji greckiego dziedzictwa na karolińskim dworze była właśnie działalność Jana Szkota Eriugeny. Informacje dotyczące filozofa przed pojawieniem się na dworze w przeważającej mierze pozostają owiane legendą. Pierwsze świadectwa pobytu w Europie kontynentalnej pochodzą z 851 roku i Eriugena był wówczas ważną postacią szkoły pałacowej króla Karola II Łysego ${ }^{16}$. Nawiązując do pytań o losy Eriugeny przed pojawieniem się na karolińskim dworze i faktu, że większość z nich pozostaje aktualnie bez odpowiedzi, Agnieszka Kijewska podkreśla, iż:

Wiadomo jedynie, że około połowy wieku IX Eriugena znalazł się na dworze Karola Łysego, wnuka Karola Wielkiego, szybko postępując po szczeblach dworskiej kariery, której zwieńczeniem mogło być stanowisko kierownika szkoły pałacowej. Być może rozpoczął swoją drogę od medycyny, ale niewątpliwie jednym $z$ ważniejszych punktów jego aktywności było nauczanie i studiowanie sztuk wyzwolonych ${ }^{17}$.

\footnotetext{
${ }^{14}$ Zob. Eriugena, Periphyseon, Ksiega I, dz. cyt., s. 9.

15 Tamże, s. 15.

${ }_{16}$ Zob. Eriugena, Komentarz, s. 4.

17 Tamże, s. 19.
} 
Ostatnie lata życia Eriugeny pozostają również owiane legendą. Z 877 roku pochodzi poemat „Aulae siderae”, co jednoznacznie świadczy, że Eriugena przebywał wówczas na karolińskim dworze. Legenda stworzona przez Wilhelma, który w XII wieku był bibliotekarzem i kronikarzem opactwa w Malmesbury podaje, iż filozof na prośbę króla Anglii, Alfreda Wielkiego, opuścił Europę kontynentalną i nauczał w przyklasztornej szkole opactwa w Malmesbury. Historycznie fakty potwierdzają, że Eriugena był jedną „(...) z najświetniejszych postaci renesansu karolińskiego (...)"18, więc jego dzieła oraz oddziaływanie stanowią swego rodzaju dziedzictwo tego okresu, dziedzictwo, które przetrwało do XXI wieku i do analizy którego zachęca papież Benedykt XVI.

\section{Kontekst historii filozofii}

Patrystyka to termin odnoszący się, w zależności od kontekstu, do jednego z działów historii powszechnej i historii Kościoła, a także do nauki badającej twórczość Ojców Kościoła lub do okresu w historii filozofii. Większość kościołów chrześcijańskich odwołuje się do patrystyki jako depozytu prawowiernej myśli chrześcijańskiej. Depozyt ten powstał w czasach, gdy nowa religia walczyła o przetrwanie i rozwój. Te uwarunkowania zrodziły dwa nurty patrystyki. Pierwszy, zwany apologetyką, koncentrował się na obronie wiary i wykazaniu jej zgodności z wymaganiami rozumu, drugi, zwany patrystyką systematyczną, koncentrował się na zgromadzeniu i ujednoliceniu poglądów dla zachowania ich spójności w coraz liczniejszych gminach. Systematycy pojęli próbę opracowania chrześcijańskiego poglądu na rzeczywistość i odegrali ważną rolę w rozwoju chrześcijańskiej filozofii. Ze względu na kryterium geograficzne i językowe, patrystyka dzieli się na Wschód, do którego należą Ojcowie greccy, na Zachód, do którego należą Ojcowie łacińscy oraz na patrystykę orientalną, do której należą Ojcowie syryjscy. Na wschodzie głównym ośrodkiem ówczesnej myśli była Aleksandria, na zachodzie Rzym. Patrystyczna myśl wschodnia wzrastała w środowiskach zamiłowania do filozoficznej spekulacji, a systemy pogańskie zachęcały do pracy nad systemem chrześcijańskim. Na Zachodzie dominowali apologeci, a środowisko rzymskie przyczyniło się do wzrostu nastrojów wrogich wobec filozofii. Przedmiotem dociekań filozoficznych, zwłaszcza wśród Ojców greckich, był niewypowiedziany i niepoznawalny absolut, a filozofia miała wypowiedzieć to,

${ }^{18}$ W. Seńko, Jak rozumieć filozofię średniowieczną, s. 111. 
co niewypowiadalne i przybliżyć to, co niepoznawalne. To zadanie realizowano za pomocą terminów negatywnych i superlatywnych. Eriugena nawiązuje do patrystyki, zwłaszcza systematycznej i konstruuje chrześcijański system filozoficzny oparty na syntezie chrześcijaństwa z systemami historycznie wcześniejszymi. Nawiązuje do rozwiązań, które wyrosły na gruncie patrystyki wschodniej, choć koncepcje autorów łacińskich można również odnaleźć w jego myśli. Patrystyczna myśl stała się inspiracją dla Eriugeny poprzez spuściznę pisarską i rozwiązania odnalezione w refleksji Grzegorza z Nazjanzu i Grzegorza z Nyssy, których wyraźnie nie rozróżniał i powoływał się na jednego Grzegorza Teologa oraz w refleksji Boecjusza, Pseudo-Dionizego Aeropagity, Maksyma Wyznawcy i świętego Augustyna. Patrystyka oddziałała na Eriugenę, choć kwestią sporną pozostaje chronologia, bo różne kryteria datowania powodują, że patrystyka nakłada się na średniowiecze. Początek patrystyki sięga czasów apostolskich, natomiast jej schyłek datuje się często na VIII wiek. Z wymienionych myślicieli, do których Eriugena nawiązywał, czasów najwcześniejszych sięga Grzegorz z Nazjanzu (329-389), choć należy pamiętać, że Jan Szkot był przekonany, iż autorem bezpośrednio żyjącym w czasach apostolskich był Pseudo-Dionizy, natomiast czasów najpóźniejszych sięga Maksym Wyznawca (580-662). Patrystyczne inspiracje Eriugeny dotyczą całego tego okresu i kończą się w VII wieku. W VIII wieku kończy się patrystyka, choć zdania są rozbieżne, bo istnieją datowania, według których patrystyka kończy się już w V wieku ${ }^{19}$, więc mimo silnego oddziaływania i wielu inspiracji, Jan Szkot nie jest reprezentantem tego okresu w historii filozofii. Myśl Eriugeny nie ma charakteru czysto patrystycznego. Filozof nie jest apologetą, nie broni chrześcijaństwa, lecz ukazuje je w nowym świetle. Jest systematykiem, jednak jego system wykracza poza samo chrześcijaństwo i nawiązuje do czasów wcześniejszych, stanowiąc syntezę chrześcijaństwa z myślą wcześniejszą. Eriugena nawiązuje do patrystyki, lecz w czasach kiedy to czyni, ten okres w historii filozofii już się skończył.

Scholastyka to wieloznaczny termin określający najczęściej średniowieczną naukę uprawianą na ówczesnych uniwersytetach, nurt teologiczny, nurt filozoficzny, metodę filozofowania oraz w czasach renesansu sofistykę i filozofię nadmiernie spekulatywną. „Termin „scholastyk” oznaczał pierwotnie mistrza kierującego szkołą, czy też w niej wykładającego, lub ogólnie - człowieka wykształconego" ${ }^{20}$. Stosując metodę scholastyczną, wybrane teksty

\footnotetext{
${ }^{19}$ Zob. R. Heinzmann, Filozofia średniowieczna, s. 25.

${ }^{20}$ W. Seńko, Jak rozumieć filozofię średniowieczną, s. 40.
} 
autorytatywne - najczęściej Pismo Święte i teksty Ojców Kościoła - objaśniano i poddawano szczegółowej dyskusji. Rozważano sprzeczne argumenty i tworzono aparaturę pojęciową, dzięki której racjonalizowano prawdy wiary. Scholastyczna wiara tak bardzo poszukiwała zrozumienia, że przeciwstawiała się filozofii. E. Gilson uznał, że scholastykę powinno przeciwstawić się prawdziwej filozofii, ponieważ

(...) każda doktryna godna miana filozofii wychodzi z konkretu i powraca do konkretu, każda natomiast scholastyka wychodzi z filozofii i powraca do filozofii. Filozofia musi wyrodzić się w scholastykę, gdy uczyni przedmiotem swych rozważań nie konkret istniejący, który powinna coraz gruntowniej zgłębiać, przenikać i wyjaśniać, ale gotowe sformułowania pewnych hipotez wyjaśniających, tak jakby same te formuły - a nie to, czego dotyczą, stanowiły rzeczywistość ${ }^{21}$.

Scholastyka dostosowywała rozum do dosłownego brzmienia autorytarnego tekstu. Wynik rozumowania był właściwy, jeżeli był zgodny z literą tekstu rozumianą najczęściej dosłownie. Eriugena nie traktował Pisma Świętego i innych tekstów autorytarnych dosłownie, choć zdarza się, że bywa zaliczany do scholastyków ze względu na relację wiary do rozumu interpretowaną w następujący sposób:

Justyn szukał niegdyś uzasadnienia zgodności między filozofią grecką a Objawieniem w tym, że już przed Chrystusem filozofia pogańska oświecona została promieniem światła nadprzyrodzonego. Eriugena zapewniał tę zgodność odwrotnie, upatrując $\mathrm{w}$ rozumie naturalnym ostateczne usprawiedliwienie samego Objawienia. Jest to stanowisko skrajnego podporządkowania wiary rozumowi. Dzięki swym poglądom na stosunek wiary do rozumu należy Eriugena do nurtu filozofii scholastycznej (choć wyznaczył on od razu skrajny jej biegun). Myśli jego zostały podane w osnowie neoplatońskiej i oparte na pismach Pseudo-Dionizego, którego Eriugena przetłumaczył i spopularyzował w średniowieczu. Paradoksalny to fakt, iż gdyby dzieła Areopagity zyskały większą popularność (na co się jakiś czas zanosiło) niż nurt boecjański, do którego i samego Eriugenę można zaliczyć, wówczas spowodowałby zapewne stłumienie myśli scholastycznej w samym jej zarodku ${ }^{22}$.

${ }^{21}$ E. Gilson, Tomizm, Wprowadzenie do filozofii św. Tomasza z Akwinu, s. 504.

${ }^{22}$ W. Seńko, Jak rozumieć filozofię średniowieczną, s. 112. 
Ojcem scholastyki nazywany bywa Anzelm z Canterbury ${ }^{23}$ żyjący w latach 1033/34-1109). Eriugena żył w latach 810-877, gdy scholastyki jeszcze nie było, a patrystyka już się skończyła. Za patrystycznymi Ojcami Wschodu Eriugena twierdził, że między objawieniem a rozumem musi panować zgoda. Tekst autorytatywny, a zwłaszcza Pismo Święte, Jan Szkot odczytywał najczęściej alegorycznie, a nie tylko dosłownie. Przyjął metodę, która dostosowywała sens tekstu do wyniku ludzkiego rozumowania. Ta metoda była całkowitym przeciwieństwem metody scholastycznej, co potwierdza tylko fakt, że Eriugena nie należy do myślicieli scholastycznych.

\section{Antyczne i chrześcijańskie inspiracje}

Jan Szkot należy do filozofów chrześcijańskich nawiązujących do patrystyki, lecz równocześnie obficie czerpie z antyku i dorobku filozofów starożytnych. Platonizm przygotował filozofię i cywilizację europejską do chrześcijaństwa, które w pierwszych wiekach czerpało z platonizmu. Twierdzenia platońskie, z którymi spotkał się Jan Szkot „(...) były przekazywane przez myślicieli chrześcijańskich, a zatem Eriugena nie widział potrzeby, ani nie był w stanie przeprowadzić ostrej granicy między platonizmem a chrześcijaństwem" ${ }^{24}$. Chrześcijanie pierwszych dwóch wieków uwiarygodnili platonizm, który dostarczał im narzędzi w obronie wiary. Późniejsi Ojcowie Kościoła, najczęściej nawiązywali do neoplatonizmu. Plotyn interesował się aktualizacją podobieństwa człowieka do Boga i problemem zbawienia, a „Chrześcijańscy neoplatonicy - również i Eriugena - podjęli tę tradycję. Chrześcijaństwo w sposób szczególny nadawało się do takiej syntezy z myślą filozoficzną, gdyż dostarczało skutecznej metody zbawienia"25. Syntezy neoplatonizmu z chrześcijaństwem dokonał między innymi Pseudo-Dionizy Aeropagita. Eriugena $\mathrm{w}$ okresie po potępieniach pracował nad przekładem jego dzieł z greki na łacinę, co rozpoczęło u filozofa proces fascynacji neoplatonizmem chrześcijańskim. Przekład został ukończony w 860 roku i złożony na ręce króla, a Eriugena, zapoznał się z syntezą neoplatonizmu i chrześcijaństwa, i wkroczył na neoplatoński szlak, którym podążał do końca życia. „Eriugena poszedł za dionizjańską, a zatem bardziej filozoficzną wersją neoplatonizmu niż

\footnotetext{
${ }^{23}$ Zob. Anzelm z Canterbury, Monologion Proslogion, przeł. Tadeusz Włodarczyk, Warszawa 1992, s. VII.

${ }^{24}$ A. Kijewska, Neoplatonizm Jana Szkota Eriugeny, Lublin 1994, s. 91.

${ }^{25}$ Tamże, s. 89.
} 
np. wersja augustyńsko-boecjańska, choć i ten ostatni nurt również jest obecny w jego pismach"26. Eriugena wymaga spójności wiary i rozumu, jednak wiarę postrzega jako zasadę, która poprzez rozum rozwija w człowieku poznanie Stwórcy ${ }^{27}$. Dokonuje się synteza filozofii i religii, a źródłem tej syntezy był neoplatonizm, który Eriugena przejął „(...) głównie ze źródeł pośrednich, $\mathrm{w}$ formie schrystianizowanej" ${ }^{28}$. Wyprowadzał $\mathrm{z}$ neoplatonizmu własne, autorskie wnioski. Za Pseudo-Dionizym przyjął, że Bóg jest „czymś nieruchomym i biegnącym zarazem, dynamicznym i statycznym, substancją i energią, tworzącym i tworzonym jednocześnie (niektóre pary przeciwieństw są powtórzeniem porównań augustyńskich). Otóż cała rzeczywistość wyczerpuje się w pojęciu tego, co tworzy i co jest tworzone (...)"29. Nawiązując do Mariusza Wiktorynusa oraz do Boecjusza uznał, że trafną nazwą dla całej rzeczywistości będzie Natura, a prawa dialektyki wykorzystane dla potrzeb epistemologicznych pozwolą na charakterystykę Boga poprzez analizę i podział Natury. Eriugena w Periphyseonie tak charakteryzuje ten podział: „Wydaje mi się, że podział natury przybiera cztery formy z powodu czworakiego zróżnicowania. Pierwszym z nich jest zróżnicowanie na tę formę, która stwarza i nie jest stworzona, drugim na tę, która stwarza i jest stworzona, trzecim na tę, która jest stworzona i nie stwarza, czwartym na tę, która ani nie stwarza, ani nie jest stworzona. Spośród tych czterech form wyłaniają się dwie pary przeciwieństw. Albowiem trzecia forma przeciwstawia się pierwszej, czwarta zaś drugiej, ale czwarta forma podpada pod kategorie tego, co niemożliwe, ponieważ jej bytem jest to, że nie może być" ${ }^{30}$. Pierwsze rozróżnienie natury to Bóg ujęty jako zasada rzeczy, natomiast czwarte rozróżnienie to również Bóg, lecz ujęty jako cel wszystkiego, co zostało stworzone. Analiza i podział rzeczywistości, podział wszystkiego, co istnieje, i co nie istnieje, a co Eriugena nazywa Naturą, wynika z neoplatonizmu i z dynamicznej koncepcji bytu Plotyna $^{31}$. O dojrzałym neoplatonizmie myśliciela świadczy najlepiej Periphyseon, w którym tworzy on neoplatońską syntezę skoncentrowaną wokół koncepcji wylewu i powrotu wszystkiego do źródła bytu, które jest ponad bytem. Eriugena jest postrzegany jako „(...) irlandzki filozof i teolog, neoplatonik,

\footnotetext{
${ }^{26}$ Tamże, s. 90.

${ }_{27}$ Zob. E. Gilson, Historia filozofii chrześcijańskiej w wiekach średnich, s. 106.

${ }^{28}$ A. Kijewska, Neoplatonizm Jana Szkota Eriugeny, s. 90.

${ }^{29}$ W. Seńko, Jak rozumieć filozofię średniowieczną, s. 130.

${ }^{30}$ Eriugena, Periphyseon, Ksiega I, s. 59-60.

${ }^{31}$ Zob. W. Stróżewski, Ontologia, s. 237.
} 
pozostający pod silnym wpływem koncepcji Pseudo-Dionizego, Boecjusza i Plotyna; (...)"32.

\section{Potępienia}

W 848 roku został wywołany spór o predestynację ${ }^{33}$. Wśród uczonych i duchownych, biorących udział w dyspucie wywołanej przez mnicha włóczęgę Gottschalka z Orbais znalazł się sam król oraz arcybiskup Hinkmar, który wraz z swym sufraganem Pardulusem z Laon zaproponowali, by Eriugena wypowiedział się w problematycznej kwestii. Udział w sporze odcisnął silne piętno na życiu i twórczości filozofa. Stanowisko Jana Szkota w kwestii predestynacji najpierw zostało przyjęte, a później podwójnie potępione - w roku 855 przez synod w Walencji oraz cztery lata później przez synod w Langres ${ }^{34}$. Ostatecznie sporu nie rozstrzygnięto i nie zaakceptowano żadnego z przedstawionych wówczas rozwiązań. Przeciwników Jana Szkota szokowała nie tylko treść odpowiedzi zawarta w dziele „De divina praedestinatione liber" ${ }^{\prime 3}$, lecz przede wszystkim przyjęta metodologia i struktura dzieła, oparta na spójnej i rzeczowej argumentacji, a jednocześnie odchodząca od powszechnie wówczas stosowanej metody katenenicznej, która ograniczała się do wyjaśniania zagadnień i rozwiązywania problemów poprzez szeregi połączonych dla doraźnej potrzeby, cytatów z pism Ojców Kościoła. Pomimo potępień, Jan Szkot pozostał na królewskim dworze. Najistotniejsze dzieła Eriugeny pochodzą z lat 859-877, a więc z czasów po potępieniach i mają charakter chrześcijański, choć po latach, papież Leon IX w 1050 roku potępił „Periphyseon” znany również jako „De divisione naturae”. Dzieło Eriugeny dodatkowo w 1225 roku papież Honoriusz III skazał na spalenie. Od czasów, w których dzieła Eriugeny powstawały, do czasów współczesnych charakterystyczne są zarzuty dotyczące panteizmu. Zarzuty te wynikają bardziej z języka, którego Eriugena używa i niezrozumienia jego rozwiązań niż z analizy treści jego dzieł.

Nic bardziej nie mogłoby nam uświadomić faktu, jak doktryna ta, mimo wprowadzającego w błąd języka, zabiega o zachowanie Boga ponad wszelkim skończonym bytem. Nawet zbawieni nie będą w wizji uszczęśliwiającej zdolni do

\footnotetext{
32 Tamże, s. 237.

${ }^{33}$ Zob. A. Kijewska, Eriugena, seria: Myśli i ludzie, Warszawa 2005, s. 19.

${ }^{34}$ Zob. Eriugena, Komentarz do Ewangelii Jana, s. 7-8.

${ }^{35}$ Zob. A. Kijewska, Eriugena, s. 20 oraz s. 120.
} 
widzenia najskrytszej tajemnicy Bóstwa. Dość dziwne jednak, że podczas gdy wielu teologów oskarży Eriugenę o mieszanie Boga ze stworzeniami, inni obwiniać go będą o całkowite oddzielenie stworzeń od Boga ${ }^{36}$.

Po patrystyce i przed scholastyką filozofia Eriugeny sprawia, że „Dzieje zbawienia w Objawieniu zostają poprzez wysiłek filozoficzny uchwycone w dosłownym tego słowa znaczeniu i ujęte w spójny i wewnętrznie logiczny system. W ten sposób Eriugena mógł, powołując się na Augustyna, utożsamić prawdziwą filozofię z prawdziwą religią" ${ }^{37}$. Jan Szkot Eriugena jest autorem systemu filozoficznego ${ }^{38}$, który stanowi syntezę filozofii i religii, a najistotniejszym źródłem tej syntezy jest neoplatonizm. „De divisione naturae jest dojrzałym i najważniejszym dla zrozumienia systemu Eriugeny dziełem. Zawiera ono wykład Szkotowej wizji Boga, człowieka i świata, wizji, która jest oryginalnym (...) rozwinięciem najbardziej podstawowych wątków neoplatonizmu"39.

\section{Zakończenie}

Wielu myślicieli nie znajdowało uznania w swoich czasach, lecz ich koncepcje oddziaływały później, co często uznawano za wyprzedzenie swej epoki. Eriugena nie podzielił losu Sokratesa i pomimo potępień cieszył się szacunkiem i przychylnością królewskiego otoczenia. Wydaje się, że ten filozof nie tylko wyprzedził swoją epokę, lecz stał się ważnym ogniwem łączącym swoje czasy z antykiem i czasy współczesne z platonizmem. Oddziaływanie autora systemu, który stanowił „(...) pierwsza metafizyczna syntezę średniowiecza"40 bywa oceniane bardzo różnie. System ten był dla łacińskiego Zachodu szansą i pokusą wybrania drogi Wschodu naznaczonej platonizmem i neoplatonizmem, jednak podejrzenia o panteizm i potępienia wykluczyły tę możliwość. „Mimo to jednak wydaje się, że dzieło Jana Eriugeny ze stulecia na stulecie wywierało w zachodnim chrześcijaństwie wpływ ukryty wprawdzie,

\footnotetext{
${ }^{36}$ E. Gilson, Historia filozofii chrześcijańskiej w wiekach średnich, s. 112-113.

${ }^{37}$ R. Heinzmann, Filozofia średniowieczna, s. 117.

${ }^{38}$ Zob. A. Kijewska, Neoplatonizm Jana Szkota Eriugeny, s. 21, 90, 106, 129.

${ }^{39}$ Eriugena, Periphyseon, Ksiega I, s. 21.

${ }^{40}$ J. Pieper, Scholastyka. Postacie i zagadnienia filozofii średniowiecznej, przełożył T. Brzostowski, Warszawa 2000, s. 46.
} 
ale bardzo ważny”41. „Daje się udowodnić wzrost jego wpływów w XII w." ${ }^{42}$. Później posiadanie pism Eriugeny groziło śmiercią, lecz fascynacja jego filozofią trwała, zwłaszcza wśród mistyków. „U progu epoki nowożytnej Mikołaj z Kuzy zaliczył Periphyseon do tekstów tak śmiałych i niezwykłych, że powinny być zastrzeżone wyłącznie dla ludzi rozumnych i mających wiedzę; (...). Wpływy Eriugeny pośrednio sięgają aż do niemieckiego idealizmu”43. Eriugena, „(...) barbarzyńca, mieszkający na krańcach świata, jak się o nim wyraził do Karola Łysego Anastazy Bibliotekarz, wzbudził wiele obaw"44. Pokazał współczesnemu sobie pokoleniu i następnym, nieznane bogactwo greckiej filozofii i teologii. Nikt po nim nie odważył się ująć całej rzeczywistości w filozoficzny system stanowiący syntezę neoplatonizmu i chrześcijaństwa. Propozycja ta, stanowiła pokusę, „(...) której zwalczania nigdy nie miały zaprzestać doktrynalne autorytety, nie udało im się bowiem nigdy zwalczyć jej ostatecznie" ${ }^{\prime 5}$. Potępione dzieła Eriugeny zdołały przetrwać i w ukryty sposób oddziaływały. Wpływy Eriugeny zdają się sięgać do współczesnej filozofii procesu. Benedykt XVI zachęca do lektury dzieł Eriugeny, wskazując, że filozof „Rozwija w nich bogate refleksje na tematy teologiczne i duchowe, które mogłyby podsunąć interesujące kierunki poszukiwań także współczesnym teologom" ${ }^{46}$. Wydaje się, że papież jednoznacznie ukazuje wartość, jaką może być inspiracja wynikająca $\mathrm{z}$ analizy dzieł Jana Szkota - oświeconego barbarzyńcy, który według jednej z legend miał zostać zakłuty rylcami studentów, bo zmuszał ich do myślenia.

Zachęcając do analizy dzieł Eriugeny i dokonując swego rodzaju rehabilitacji filozofa po jednoznacznych decyzjach Leona IX i Honoriusza III, Benedykt XVI zwraca uwagę na jego wyjątkowość, mówiąc wprost „Był człowiekiem nadzwyczajnym, który w tym okresie władał również językiem greckim" ${ }^{47}$. Papież przypomina, że Eriugena, będąc przekonany o ich apostolskim charakterze, przetłumaczył na łacinę dzieła Dionizego Areopagity. „Wielcy teologowie średniowieczni, tacy jak św. Bonawentura, poznali dzieła Dionizego dzięki temu przekładowi”"48. Benedykt XVI zwraca szczególną uwagę na

\footnotetext{
${ }^{41}$ Tamże, s. 46.

${ }^{42}$ R. Heinzmann, Filozofia średniowieczna, przeł. P. Domański, Kęty 1999, s. 128.

${ }^{43}$ Tamże, s. 128.

${ }^{44}$ E. Gilson, Historia filozofii chrześcijańskiej w wiekach średnich, Warszawa 1987, s. 118.

${ }^{45}$ Tamże, s. 118.

${ }^{46}$ Benedykt XVI, Jan Szkot Eriugena...

47 Tamże.

${ }^{48}$ Tamże.
} 
stanowisko Eriugeny w kwestii konieczności niestrudzonego poszukiwania prawdy; wiary stanowiącej początek zbawienia; bezwzględnej wartości Pisma Świętego pochodzącego od zawsze prawdomównego Boga; autorytetu, który nigdy nie może być sprzeczny z ludzkim rozumem, bo Stwórcą rozumu jest sam Bóg. Myśl Eriugeny, zdaniem Benedykta XVI, w kwestii interpretacji Biblii, która została dana ludzkości, bo człowiek będąc w stanie rajskim zgrzeszył, może współcześnie „(...) wskazać właściwą drogę do poprawnego odczytania Pisma Świętego" ${ }^{49}$, dzięki któremu racjonalna ludzka natura może zbliżyć się do tajemnic, których ślady odnajduje w sobie. Współczesna wartość stanowiska Eriugeny w kwestii egzegezy wynika zdaniem Benedykta XVI z faktu, że „Chodzi (...) o odkrycie ukrytego sensu świętego tekstu, co zakłada szczególne ćwiczenie wewnętrzne, dzięki któremu rozum otwiera się, by pewną drogą iść do prawdy" ${ }^{50}$. Proponowana przez Eriugenę harmonia wiary i rozumu w symboliczny sposób zostaje wyrażona w formule: nikt nie wejdzie do nieba inaczej niż przez filozofię ${ }^{51}$. Benedykt XVI zachęca do lektury dzieł Jana Szkota, dostrzegając w nich pewną aktualność i źródło ciekawych inspiracji dla myślicieli XXI wieku.

\section{Bibliografia}

Anzelm z Canterbury, Monologion Proslogion, przeł. Tadeusz Włodarczyk, wstęp i przegl. Iwo Edward Zieliński, Biblioteka Klasyków Filozofii, PWN, Warszawa 1992.

Benedykt XVI, Jan Szkot Eriugena, Audiencja Generalna 10 czerwca 2009 roku, „L'Osservatore Romano” 9/2009.

Eriugena Jan Szkot, Annotationes in Marcianum, no. 64; translation from John Joseph O’Meara Eriugena, Clarendon Press, Oxford 1988.

Eriugena Jan Szkot, Komentarz do Ewangelii Jana z Homilia do Prologu Ewangelii Jana, przeł. A. Kijewska, ANTYK, Kęty 2000.

Eriugena Jan Szkot, Periphyseon, Księga I, przeł., wstępem i komentarzami opatrzyła Agnieszka Kijewska, Wydawnictwo Marek Derewiecki, Kęty 2009.

Faber G., Merowingowie i Karolingowie, przeł. Z. Jaworski, PIW, Warszawa 1994.

Gilson E., Historia filozofii chrześcijańskiej w wiekach średnich, przeł. S. Zalewski, PAX, Warszawa 1987.

\footnotetext{
49 Tamże.

50 Tamże.

${ }^{51}$ Eriugena, Annotationes in Marcianum, no. 64; translation from John Joseph O'Meara Eriugena, 1988, s. 30.
} 
Gilson E., Tomizm. Wprowadzenie do filozofi św. Tomasza z Akwinu, przeł. J. Rybałt, PAX, Warszawa 2003.

Heinzmann R., Filozofia średniowieczna, przeł. P. Domański, ANTYK, Kęty 1999. Kijewska A., Eriugena, Wyd. Wiedza Powszechna, Warszawa 2005.

Kijewska A., Neoplatonizm Jana Szkota Eriugeny, Redakcja Wydawnictw Katolickiego Uniwersytetu Lubelskiego, Lublin 1994.

Manteuffel T., Historia Powszechna. Średniowiecze, PWN, Warszawa 1996.

Michałowski R., Historia powszechna. Średniowiecze, Wyd. PWN, Warszawa 2009. Pieper J., Scholastyka. Postacie i zagadnienia filozofii średniowiecznej, przeł. T. Brzostowski, PAX, Warszawa 2000.

Seńko W., Jak rozumieć filozofię średniowieczną, Wyd. ANTYK, Kęty 2001.

Strzelczyk J., Iroszkoci w kulturze średniowiecznej Europy, PIW, Warszawa 1987.

Stróżewski W., Ontologia, Aureus - Znak, Kraków 2004.

\author{
Abstract \\ Eriugena in Context of the National Origin, World History \\ and the History of Philosophy
}

In 2009 XVI Benedict during the general audience suggested the short deliberation concerning the thought of Eriugeny - of philosopher, of which views fourfold were condemned. The thinker living in the 9th century went regarded as the Englishman or the Irishman, of representative of periods in the history of philosophy which before his times managed to end or of which in his times not yet was. He is ranked among the Middle Ages and classified as the Neo-Platonist, the representative of Patristics and the scholastic. His concept was being included as the reprehensible pantheistical evocation or Patristics systematics. In applying Eriugeny publications it is possible to come across a lot of divergences which most often concern the nationality of the thinker, although it seems that this issue after all was clarified, of classification of his times in the context of the European world history and classification of his thought in the history of philosophy. XVI Benedict is encouraging Eriugeny for analysis of work and is pointing at the topicality of his views, it is worthwhile so according to the author's making an attempt to portray the philosopher in three contexts: ethnic, historical and philosophical, the most devoting the attention to the philosophical context.

Key words: Eriugena, XVI Benedict, philosophy, Neo-Platonism, Christianity, Patristics, the Renaissance, scholasticism 